\title{
Impact of Sinorhizobium meliloti Exopolysaccharide on Adsorption and Aggregation in the Copper(II) Ions/Supporting Electrolyte/Kaolinite System
}

\author{
Katarzyna Szewczuk-Karpisz ${ }^{1, *(\mathbb{D})}$, Agnieszka Tomczyk ${ }^{1}{ }^{\circledR}$, Iwona Komaniecka ${ }^{2} \mathbb{D}$, Adam Choma ${ }^{2}$, \\ Agnieszka Adamczuk ${ }^{1}$ and Weronika Sofińska-Chmiel ${ }^{3}$ \\ 1 Institute of Agrophysics, Polish Academy of Sciences, Doświadczalna 4, 20-290 Lublin, Poland; \\ a.tomczyk@ipan.lublin.pl (A.T.); a.adamczuk@ipan.lublin.pl (A.A.) \\ 2 Department of Genetics and Microbiology, Institute of Biological Sciences, Maria Curie-Sklodowska \\ University, Akademicka 19, 20-033 Lublin, Poland; iwona.komaniecka@poczta.umcs.lublin.pl (I.K.); \\ adam.choma@poczta.umcs.lublin.pl (A.C.) \\ 3 Analytical Laboratory, Institute of Chemical Sciences, Faculty of Chemistry, Maria Curie-Sklodowska \\ University, Maria Curie-Sklodowska Sq. 3, 20-031 Lublin, Poland; wschmiel@poczta.umcs.lublin.pl \\ * Correspondence: k.szewczuk-karpisz@ipan.lublin.pl
}

\section{check for}

updates

Citation: Szewczuk-Karpisz, K.; Tomczyk, A.; Komaniecka, I.; Choma, A.; Adamczuk, A.; Sofińska-Chmiel, W. Impact of Sinorhizobium meliloti Exopolysaccharide on Adsorption and Aggregation in the Copper(II) Ions/Supporting Electrolyte/ Kaolinite System. Materials 2021, 14, 1950. https://doi.org/10.3390/ ma14081950

Academic Editor: Tamas Varga

Received: 5 March 2021

Accepted: 10 April 2021

Published: 13 April 2021

Publisher's Note: MDPI stays neutral with regard to jurisdictional claims in published maps and institutional affiliations.

Copyright: (c) 2021 by the authors. Licensee MDPI, Basel, Switzerland. This article is an open access article distributed under the terms and conditions of the Creative Commons Attribution (CC BY) license (https:// creativecommons.org/licenses/by/ $4.0 /)$.

\begin{abstract}
To obtain insight into physicochemical interactions between $\mathrm{Cu}(\mathrm{II})$ ions, kaolinite, and exopolysaccharide (EPS) synthesized by Sinorhizobium meliloti Rm 1021 soil bacteria, an adsorption, electrokinetic, and aggregation study was performed in the selected systems. The obtained data showed that supporting electrolyte type affects both EPS and $\mathrm{Cu}$ (II) ions adsorption. For initial $\mathrm{Cu}(\mathrm{II})$ concentration $100 \mathrm{mg} / \mathrm{L}, 4.36 \pm 0.25 \mathrm{mg} / \mathrm{g}(21.80 \pm 1.00 \%)$ of the ions were adsorbed in $0.001 \mathrm{M}$ $\mathrm{NaCl}$ and $3.76 \pm 0.20 \mathrm{mg} / \mathrm{g}(18.80 \pm 1.00 \%)$ in $0.001 \mathrm{M} \mathrm{CaCl}_{2}$. The experimental data were best fitted to the Langmuir model as well as pseudo second-order equation. The EPS adsorbed amount on kaolinite was higher in the $\mathrm{CaCl}_{2}$ electrolyte than in $\mathrm{NaCl}$ one. For an initial polymer concentration of $100 \mathrm{mg} / \mathrm{L}$, the EPS adsorbed amount was $4.69 \pm 0.08 \mathrm{mg} / \mathrm{g}(23.45 \pm 0.40 \%)$ in $0.001 \mathrm{M} \mathrm{NaCl}$ and $5.26 \pm 0.15 \mathrm{mg} / \mathrm{g}(26.32 \pm 0.75 \%)$ in $0.001 \mathrm{M} \mathrm{CaCl}_{2}$. In the mixed system, regardless of electrolyte type, exopolysaccharide contributed to immobilization of higher amount of copper(II) ions on the clay mineral. Also, in the samples containing heavy metal ions and exopolysaccharide simultaneously, the aggregation of kaolinite particles was the strongest. The results presented in the paper may be very helpful in soil bioremediation, especially in the development of technologies reducing the mobility of heavy metals in the environment.
\end{abstract}

Keywords: adsorption mechanism; single and mixed systems; surface charge density; zeta potential; CPS analysis; turbidimetry

\section{Introduction}

The main aim of symbiosis between Sinorhizobium bacteria and Fabaceae plants is to enable the fixation of atmospheric nitrogen. At the beginning, soil bacteria penetrate into the plant through the root hairs. Then, an infection thread is created, which introduces the microorganisms deep into the plant's tissue (primary cortex). The next step is formation of the root nodule, inside which the bacteria is transformed into bacteroids-the forms enable to atmospheric nitrogen fixation. Within the root nodules, the synthesis of proteins and enzymes necessary for $\mathrm{N}_{2}$ reduction occurs [1]. One of the most important factors in establishing symbiosis between bacteria and legume plant is exopolysaccharide (EPS) - a macromolecular compound produced by microorganisms and excreted into the environment [2].

Bacterial exopolysaccharides are large, long-chain biopolymers. They are composed of repeating oligosaccharidic subunits formed by carbohydrate monomers linked by $\alpha$ - 
and $\beta$-glycosidic bonds. EPS can be attached to the surface of cells forming an envelope (capsular polysaccharide-CPS) or can be secreted outside the cells as mucus (slime exopolysaccharide) [3]. Bacteria Sinorhizobium meliloti $\mathrm{Rm} 1021$ synthesize two types of exopolysaccharide. The first, called EPS I, is a succinylglycan composed of octasaccharide subunits containing seven glucose molecules and one galactose molecule linked by $\beta-1,3$, $\beta-1,4$ and $\beta-1,6$ glycosidic bonds [4]. Succinylglycan is modified with succinyl, pyruvyl, and acetyl groups substituting the sugar backbone [5]. EPS I occurs in two fractions:

1. HMW (high molecular weight) characterized by molecular weight equal to $10^{6}-10^{7} \mathrm{Da}$, as well as

2. LMW (low molecular weight) composed of monomers, dimers and trimers of octasaccharide subunits $[4,5]$.

It has been shown that the LMW form is more biologically active and necessary for the development of effective nodules [2,6]. The second type of exopolysaccharide-EPS II, is a galactoglucan made of disaccharide basic units of acetylated glucose and galactose linked by $\beta-1,3$ and $\alpha-1,3$ glycosidic bonds, substituted with a pyruvic acid and acetyl residue [4]. Exopolysaccharide plays a key role in the protection against pathogens (bacteriophages) as well as adverse environmental factors (extreme temperature or $\mathrm{pH}$ ) [3]. What is more, it may influence the immobilization of heavy metals in the soil environment.

Soil pollution with heavy metals is mainly caused by emissions from rapidly expanding industrial areas, e.g., mine tailings, sewage sludge, pesticides, wastewater irrigation, atmospheric deposition and others [7]. Metal and non-metal ions can persist for a long time in the environment and pose a serious threat to animals and plants. These hazardous compounds decrease food quality (safety and marketability) via phytotoxicity and reduce land usability for agricultural production [8]. Most metals do not undergo microbial or chemical degradation [9]. Moreover, some of them inhibit the biodegradation of organic contaminants [7]. Heavy metals accumulated in soils can be released into other ecosystems and pollute surface and ground waters penetrating various food chains (soil-plant-human or soil-plant-animal-human) [8]. This migration occurs in the liquid and solid phases based on four major mechanisms: ion exchange, complexation, sorption and precipitation [10]. One approach for limiting mobility of pollutants is soil remediation using specific substances. The applied compounds reduce solubility and bioavailability of harmful elements as well as prevent their leaching to the aqueous ecosystems.

Recently, several scientists focused on the impact of polymeric substances, $\mathrm{pH}$ and temperature on the adsorption of metal or non-metal ions on clay minerals. For example, Fijałkowska et al. [11] found that lead(II) had a stronger affinity to the kaolinite surface in the presence of anionic polyacrylamide. The same team [12] observed that cationic polyacrylamide adsorbed on the kaolinite surface contributed to higher adsorption level of chromium(VI) ions. These phenomena were associated with the formation of polymerheavy metal ion complexes. The ion adsorption on kaolinite was also dependent on the solution $\mathrm{pH}$ value. The lower $\mathrm{pH}$ value was, the larger adsorption capacity relative to $\mathrm{Cr}(\mathrm{VI})$ ions was observed. Jiang et al. [13] described the adsorption of copper(II) ions onto natural kaolinite clay. The adsorption capacity of the selected solid was higher at lower $\mathrm{pH}$ values. On the other hand, Wu et al. [14] showed that adsorptive abilities relative to $\mathrm{Cu}$ (II) ions of clay minerals were significantly improved due to their modification by humic acids.

The effect of bacterial exopolysaccharides on adsorptive properties of soil minerals is rarely described. Therefore, the authors investigated the physicochemical interactions between the exopolysaccharide Sinorhizobium meliloti Rm 1021, copper(II) ions and kaolinite. The performed study included:

1. adsorbed amount measurements of $\mathrm{Cu}(\mathrm{II})$ ions and EPS on kaolinite in the single and mixed systems (i.e., containing one or two adsorbates);

2. confirmation of $\mathrm{Cu}(\mathrm{II}) / \mathrm{EPS}$ adsorption using scanning electron microscope with EDS analyzer and Fourier transform infrared spectroscopy;

3. determination of surface charge density and zeta potential of kaolinite without and with $\mathrm{Cu}(\mathrm{II})$ ions and/or EPS; 
4. aggregation study on kaolinite in the absence and presence of $\mathrm{Cu}(\mathrm{II})$ ions and/or EPS using turbidimetry and particle size analyzer (CPS).

The authors hypothesized that bacterial exopolysaccharide contributes to the adsorption of larger amount of copper(II) ions on the kaolinite surface and causes a strong aggregation of this clay mineral. The presented results can be very helpful in the development of innovative procedures for the treatment of soil or groundwater.

\section{Materials and Methods}

\subsection{Materials}

Kaolinite (CAS 1318-74-7), a clay mineral of 1:1 structure, delivered by Sigma-Aldrich (Saint Louis, MO, USA), was used in the study. Textural parameters of the selected solid were determined using nitrogen adsorption/desorption method (Micromeritics ASAP 2020 analyzer, Norcross, GA, USA). Kaolinite is an aluminosilicate of low porosity parameters. Its specific surface area equals $8.02 \mathrm{~m}^{2} / \mathrm{g}$, while total pore volume $\left(\mathrm{V}_{\mathrm{p}}\right)$ is $0.0287 \mathrm{~cm}^{3} / \mathrm{g}$. It contains two groups of mesopores of average diameters equal to 3.8 and $11.7 \mathrm{~nm}$ [12].

Sinorhizobium meliloti exopolysaccharide (EPS) and copper(II) ions were also used in the experiments. EPS was isolated at the Institute of Biological Sciences, UMCS, Lublin, Poland. The bulk EPS solution had a concentration of $500 \mathrm{mg} / \mathrm{L}$, whereas the $\mathrm{Cu}$ (II) one$1000 \mathrm{mg} / \mathrm{L}$. Copper(II) ions were applied in the form of $\mathrm{CuCl}_{2}$ (Sigma Aldrich, Saint Louis, MO, USA; CAS 7447-39-4). The $\mathrm{pK}_{\mathrm{a}}$ value of $S$. meliloti exopolysaccharide, determined by potentiometric titration, was equal to 3.8 [15]. At $\mathrm{pH} 5$, the dissociation degree $(\alpha)$ of selected polymer was 0.94 .

The probes for adsorption, complexation, electrokinetic and aggregation studies were prepared using two types of supporting electrolyte, i.e., sodium chloride $(\mathrm{NaCl})$ and calcium chloride $\left(\mathrm{CaCl}_{2}\right)$ with the concentration of $0.001 \mathrm{M}$. The $\mathrm{pH}$ value of the examined samples was adjusted using $0.1 \mathrm{M} \mathrm{HCl}, 0.1 \mathrm{M} \mathrm{NaOH}$ and multifunction meter CX-505 (Elmetron, Zabrze, Poland).

\subsection{Methods}

\subsubsection{EPS Isolation}

Exopolysaccharide of Sinorhizobium meliloti $\mathrm{Rm} 1021$ was isolated according to the following procedure. At first, S. meliloti culture was carried on in 2-littre flasks containing 1 L 79CA medium containing glycerol and succinate as carbon sources [16], for $48 \mathrm{~h}$, under continuous shaking $(120 \mathrm{rpm})$, at $28^{\circ} \mathrm{C}$. Then, the bacteria were separated from the medium by centrifugation ( $30 \mathrm{~min}, 9000 \mathrm{rpm}$ ). The obtained supernatant was concentrated using vacuum evaporator and dialyzed by distilled water by 3 days. The EPS precipitation was performed using cold ethanol (3 volumes per 1 volume of EPS) and cooled $\left(-20^{\circ} \mathrm{C}, 24 \mathrm{~h}\right)$. The resulting EPS precipitate was sedimented by centrifugation $\left(30 \mathrm{~min}, 4^{\circ} \mathrm{C}, 8000 \mathrm{rpm}\right)$, and obtained pellet was resuspended in deionised water and lyophilized.

\subsubsection{Adsorption Study}

The adsorbed amount of EPS or copper(II) ions $(\Gamma, \mathrm{mg} / \mathrm{g})$ on the kaolinite surface was established based on the difference in the adsorbate concentration in the solution before $\left(\mathrm{C}_{0}\right)$ and after $\left(\mathrm{C}_{\mathrm{eq}}\right)$ the adsorption according to the Equation (1) [17]:

$$
\Gamma=\frac{\mathrm{C}_{\mathrm{ads}} \cdot \mathrm{V}}{\mathrm{m}}
$$

where $\mathrm{C}_{\mathrm{ads}}(\mathrm{mg} / \mathrm{L})$ denotes the $\mathrm{EPS} / \mathrm{Cu}$ (II) ions amount adsorbed on the surface $\left(\mathrm{C}_{\mathrm{ads}}=\mathrm{C}_{0}-\mathrm{C}_{\mathrm{eq}}\right), \mathrm{V}(\mathrm{L})$ is the suspension volume, and $\mathrm{m}(\mathrm{g})$ is the adsorbent weight in the suspension.

The samples for the study were prepared by adding $0.05 \mathrm{~g}$ of kaolinite to the suspension containing supporting electrolyte as well as selected adsorbate (EPS or $\mathrm{Cu}(\mathrm{II})$ ) or two adsorbates simultaneously. The optimal solid weight was selected based on the previous study on $\mathrm{Cu}(\mathrm{II})$ adsorption on various solid weights. After adjustment of the $\mathrm{pH}$ value to 5 , 
the adsorption was started. The above $\mathrm{pH}$ value reflects the common conditions of Polish soils. Moreover, it was the highest $\mathrm{pH}$ value, at which copper occurs mainly as $\mathrm{Cu}^{2+}$ ions in the solution. The adsorption process was conducted for $24 \mathrm{~h}$ to ensure an equilibrium state in the studied systems. After its completion, the suspensions were filtered using paper filters and the obtained supernatants were analyzed to determine the copper(II) ions concentration by Mehling method [18] or EPS concentration by TOC analyzer (Multi N/C 2000, HT 1300, Analytik Jena, Jena, Germany). The adsorption isotherms of copper(II) ions were obtained for the initial $\mathrm{Cu}(\mathrm{II})$ concentrations in the range of $10-250 \mathrm{mg} / \mathrm{L}$. These $\mathrm{Cu}(\mathrm{II})$ concentrations gave a plateau in adsorption isotherms. The obtained data were fitted to selected theoretical models, i.e., Langmuir (Equation (2)) and Freundlich (Equation (3)) [19]:

$$
\begin{gathered}
\mathrm{q}_{\mathrm{e}}=\frac{\mathrm{q}_{\mathrm{m}} \mathrm{K}_{\mathrm{L}} \mathrm{C}_{\mathrm{e}}}{1+\mathrm{K}_{\mathrm{L}} \mathrm{C}_{0}} \\
\mathrm{q}_{\mathrm{e}}=\mathrm{K}_{\mathrm{F}} \mathrm{C}_{\mathrm{e}}^{1 / \mathrm{n}}
\end{gathered}
$$

where $\mathrm{K}_{\mathrm{F}}\left(\mathrm{mg} / \mathrm{g}(\mathrm{mg} / \mathrm{L})^{-1 / n F}\right)$ is the Freundlich parameter, $\mathrm{K}_{\mathrm{L}}(\mathrm{L} / \mathrm{mg})$ is the Langmuir parameter, $\mathrm{q}_{\mathrm{e}}(\mathrm{mg} / \mathrm{g})$ is the equilibrium adsorption capacity, $\mathrm{C}_{\mathrm{e}}(\mathrm{mg} / \mathrm{L})$ is the equilibrium liquid phase concentration, $\mathrm{q}_{\mathrm{m}}(\mathrm{mg} / \mathrm{g})$ is the maximum adsorption capacity in Langmuir model, and $\mathrm{n}$ is the Freundlich constant related to adsorption intensity.

The specific surface area occupied by the copper ions $\left(\mathrm{S}_{\mathrm{i}}\right)$ at equilibrium was calculated from the following Equation:

$$
S_{i}=\frac{q_{m} N A_{i}}{M}
$$

where: $\mathrm{N}$-Avogadro number, $\mathrm{A}_{\mathrm{i}}\left(\mathrm{m}^{2}\right)$ —metal ion cross-sectional area, $\mathrm{M}(\mathrm{g})$-ion molecular mass.

The obtained parameters showed the conditions, under which kaolinite is more effective adsorbent [20].

Due to the fact that the adsorption of macromolecular compound does not meet the assumptions of Langmuir and Freundlich models, the isotherms for exopolysaccharide were not obtained and modeled. The EPS adsorbed amounts were presented as histograms for the initial polymer concentration equal to $100 \mathrm{mg} / \mathrm{L}$. In the mixed systems, i.e., containing $\mathrm{Cu}(\mathrm{II})$ ions and EPS in the same time, the initial concentration of two adsorbates was also $100 \mathrm{mg} / \mathrm{L}$. The adsorption efficiency (E, \%) was calculated using the Equation:

$$
\mathrm{E}=\frac{\mathrm{C}_{\mathrm{ads}}}{\mathrm{C}_{0}} \cdot 100 \%
$$

where $\mathrm{C}_{\mathrm{ads}}$-the concentration of adsorbed ions $(\mathrm{mg} / \mathrm{L}), \mathrm{C}_{0}$-the initial concentration $(\mathrm{mg} / \mathrm{L})$.

Kinetics of $\mathrm{Cu}(\mathrm{II})$ adsorption on kaolinite were determined in the probes containing $100 \mathrm{mg} / \mathrm{L}$ of heavy metal ions, at $\mathrm{pH}$. The $\mathrm{Cu}(\mathrm{II})$ adsorbed amount was measured after adsorption process lasting 5, 10, 30, 60, 90, 120, 180, 240, $300 \mathrm{~min}$. The obtained results were modeled using pseudo first-order Equation (6) and pseudo second-order Equation(7) [21,22]:

$$
\begin{aligned}
\frac{d q_{t}}{d t} & =k_{2}\left(q_{e}-q_{t}\right) \\
\frac{d q_{t}}{d t} & =k_{2}\left(q_{e}-q_{t}\right)^{2}
\end{aligned}
$$

where: $\mathrm{q}_{\mathrm{e}}$-the adsorbed amount at equilibrium $[\mathrm{mg} / \mathrm{g}], \mathrm{q}_{\mathrm{t}}$-the adsorbed amount after time $^{\prime} \mathrm{t}^{\prime}(\mathrm{mg} / \mathrm{g}), \mathrm{k}_{1}(1 / \mathrm{min})$ and $\mathrm{k}_{2}(\mathrm{~g} / \mathrm{mg} \cdot \mathrm{min})$ — the equilibrium rate constants.

A single result was the average of three repetitions. The measurement error did not exceed $5 \%$.

EPS adsorption on the kaolinite surface was also confirmed using Nicolet 6700 FTIR spectrometer (Thermo Scientific, Madison, WI, USA) equipped with Smart Orbit Diamond 
diamond attenuated reflectance (ATR) attachment. The spectra of kaolinite, EPS and kaolinite covered with EPS were recorded between 4000 and $400 \mathrm{~cm}^{-1}$ at $4 \mathrm{~cm}^{-1}$ intervals. Each spectrum was obtained from 128 scans and corrected with a linear baseline using OMNIC (v.8.2, Thermo Scientific, Madison, WI, USA).

\subsubsection{Complexes Formation Study}

Complexes formation between exopolysaccharide and copper(II) ions was investigated analogously to the adsorption measurements. At the beginning, the probes containing $100 \mathrm{mg} / \mathrm{L}$ of EPS, $100 \mathrm{mg} / \mathrm{L}$ of $\mathrm{Cu}(\mathrm{II})$ ions, and $0.001 \mathrm{M}$ of supporting electrolyte were prepared. Then, the $\mathrm{pH}$ value of the solutions was adjusted to 5 . After $24 \mathrm{~h}$ continuous shaking, the samples were centrifuged 3 times and the obtained supernatants were analyzed towards determination of copper ions concentration in them [18]. A single result was the average of three repetitions. The measurement error did not exceed $5 \%$.

\subsubsection{Surface Charge Determination}

Surface charge density $\left(\sigma_{0}\right)$ of kaolinite in the absence and presence of copper(II) ions and S. meliloti exopolysaccharide was determined using potentiometric titration (Titrino 702 SM burette, Metrohm, Herisau, Switzerland). The following systems were titrated:

1. supporting electrolyte $(0.001 \mathrm{M} \mathrm{NaCl}$ or $\mathrm{CaCl} 2)$;

2. supporting electrolyte + kaolinite

3. $\quad$ supporting electrolyte + kaolinite $+\mathrm{Cu}(\mathrm{II})$ ions;

4. $\quad$ supporting electrolyte + kaolinite + EPS;

5. $\quad$ supporting electrolyte + kaolinite $+\mathrm{Cu}$ (II) ions + EPS.

The concentration of adsorbates was equal to $100 \mathrm{mg} / \mathrm{L}$. The mass of kaolinite using to the suspension preparation was $0.1 \mathrm{~g}$. The titrations of the systems without heavy metal were carried out in the $\mathrm{pH}$ range 3.5-10. In turn, in order to avoid the hydroxide precipitation, the measurements of the suspensions with $\mathrm{Cu}(\mathrm{II})$ ions were performed in the $\mathrm{pH}$ range 3.5-6. The $\sigma_{0}$ parameter was calculated using the following formula [23]:

$$
\sigma_{0}=\frac{\Delta \mathrm{V} \cdot \mathrm{C} \cdot \mathrm{F}}{\mathrm{m} \cdot \mathrm{S}_{\mathrm{BET}}}
$$

where: $\Delta \mathrm{V}(\mathrm{mL})$ - the difference in the base volume added to the suspension and the supporting electrolyte that leads to the specific $\mathrm{pH}$ value, $\mathrm{C}(\mathrm{mol} / \mathrm{L})$ - the base concentration, $\mathrm{F}$ - the Faraday constant, $\mathrm{m}(\mathrm{g})$ - the solid mass in the suspension, $\mathrm{S}_{\mathrm{BET}}\left(\mathrm{m}^{2} / \mathrm{g}\right)$ - the solid surface area.

\subsubsection{Zeta Potential Calculation}

Electrophoretic mobility of the kaolinite particles without and with $\mathrm{Cu}(\mathrm{II})$ ions/exopoly saccharide was determined using microelectrophoresis phenomenon, i.e., zetasizer NanoZS (Malvern Instruments, Worcestershire, UK). Based on obtained results, zeta potential ( $\zeta$ ) of the selected solid was calculated by the computer software [24]. The suspensions for the experiment were prepared by adding $0.2 \mathrm{~g}$ of kaolinite to $200 \mathrm{~mL}$ of the solution containing supporting electrolyte $\left(0.001 \mathrm{M} \mathrm{NaCl}\right.$ or $\left.\mathrm{CaCl}_{2}\right)$ without or with $\mathrm{Cu}$ (II) ions/exopolysaccharide. Such suspensions were divided into several parts of different $\mathrm{pH}$ values (3-9 in the case of the systems without $\mathrm{Cu}$ (II) ions, 3-6 in the case of the systems containing heavy metal ions). The concentration of $\mathrm{Cu}(\mathrm{II})$ ions and exopolysaccharide used in the suspension preparation was equal to $100 \mathrm{mg} / \mathrm{L}$.

\subsubsection{Aggregation study}

The aggregation of kaolinite particles was established based on the turbidimetric measurements (Hach 2100AN turbidimeter, Omc Envag, Warsaw, Poland) as well as CPS analyses (DC24000 analyzer, CPS Instruments, Anaheim, CA, USA). The samples were prepared by addition $0.02 \mathrm{~g}$ of kaolinite to supporting electrolyte $\left(0.001 \mathrm{M} \mathrm{NaCl}\right.$ or $\left.\mathrm{CaCl}_{2}\right)$. 
After $3 \mathrm{~min}$ sonication, the one or two adsorbates ( $\mathrm{Cu}(\mathrm{II})$ ions or exopolysaccharide with the concentration of $100 \mathrm{mg} / \mathrm{L}$ ) were added (the final volume of the sample was $20 \mathrm{~mL}$ ). After $\mathrm{pH}$ adjustment to the value of 5, the CPS or turbidimetric analysis was started. A single measurement of system turbidity lasted $60 \mathrm{~min}$. CPS analyses were performed using sucrose gradient, prepared by mixing $8 \%$ and $24 \%$ solutions. The disc speed was equal to $2500 \mathrm{rpm}$. The particle/aggregate size was measured in the diameter range of $0.11-5 \mu \mathrm{m}$.

\section{Results and Discussion}

\subsection{Mechanism of Copper(II) Ions Adsorption on Kaolinite}

The results of $\mathrm{Cu}$ (II) adsorption kinetics on kaolinite, presented in Figure 1a, showed that equilibrium in the examined systems was reached after $90 \mathrm{~min}$ in both supporting electrolyte types.

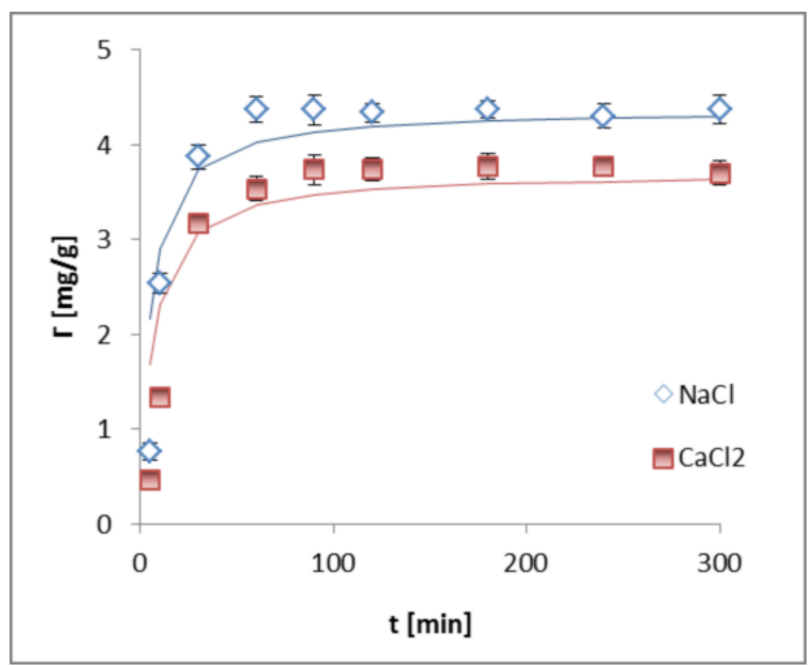

(a)

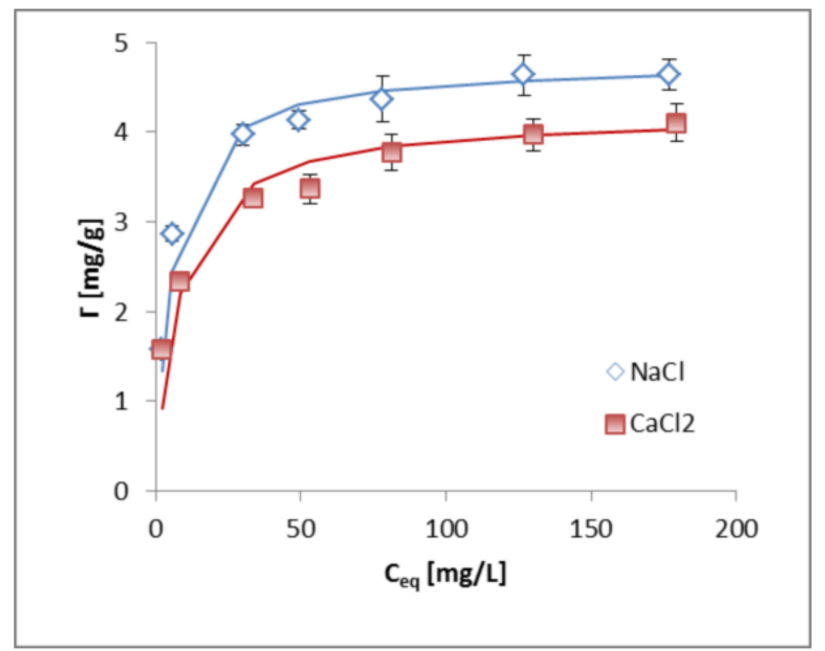

(c)

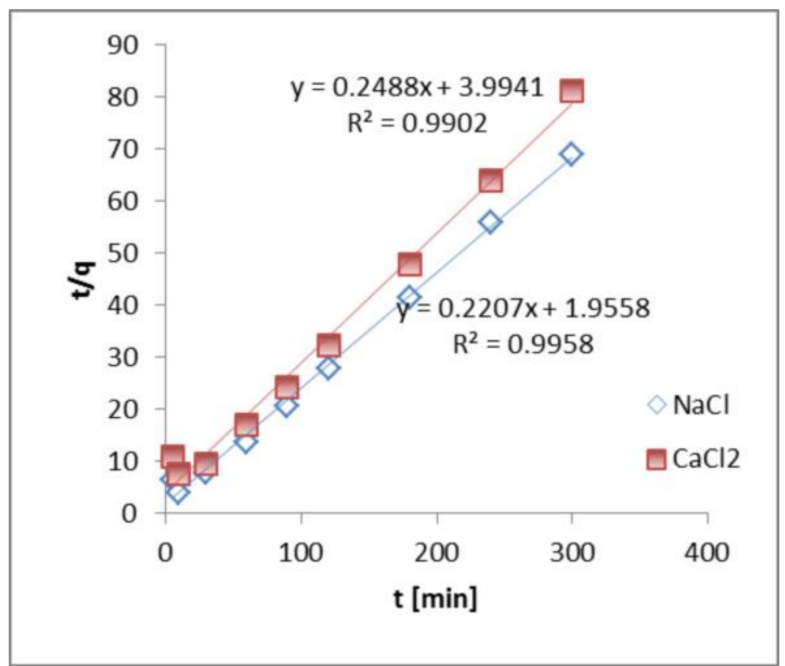

(b)

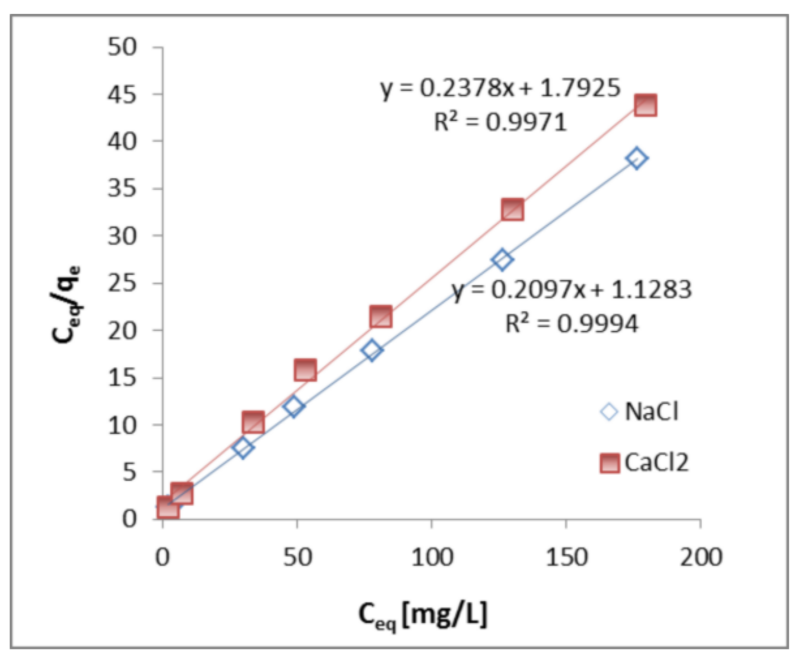

(d)

Figure 1. Copper(II) ion adsorption kinetics on kaolinite: data (points) and pseudo second-order fitting (lines) in the $\mathrm{NaCl}$ or $\mathrm{CaCl}_{2}$ solution (a) as well as the obtained linear forms of PSO Equation (b); Adsorption isotherms of copper(II) ions on kaolinite: data (points) and Langmuir fitting (lines) (c) as well as their linear forms (d); at $\mathrm{pH} \mathrm{5,} \mathrm{in} \mathrm{the} \mathrm{NaCl}$ or $\mathrm{CaCl}_{2}$ solution. 
The obtained data were better fitted to the pseudo second-order (PSO) equation than to the pseudo first-order (PFO) one (Figure 1a, Table 1).

Table 1. Kinetics and isotherm parameters acquired from selected models of $\mathrm{Cu}(\mathrm{II})$ adsorption on kaolinite, at $\mathrm{pH} 5$, in the $\mathrm{NaCl}$ or $\mathrm{CaCl}_{2}$ solution.

\begin{tabular}{|c|c|c|c|c|c|c|c|}
\hline & & \multicolumn{3}{|c|}{ Pseudo I-Order Equation } & \multicolumn{3}{|c|}{ Pseudo II-Order Equation } \\
\hline \multicolumn{2}{|c|}{ System } & $\begin{array}{c}\mathrm{qe}_{\mathrm{e}} \\
{[\mathrm{mg} / \mathrm{g}]}\end{array}$ & $\begin{array}{c}\mathrm{k}_{1} \\
{[1 / \mathrm{min}]}\end{array}$ & $\mathrm{R}^{2}$ & $\begin{array}{c}\mathrm{q}_{\mathrm{e}} \\
{[\mathrm{mg} / \mathrm{g}]}\end{array}$ & $\begin{array}{c}\mathrm{k}_{2} \\
{[\mathrm{~g} /(\mathrm{mg} \cdot \mathrm{min})]}\end{array}$ & $\mathrm{R}^{2}$ \\
\hline \multirow[t]{3}{*}{ Kinetics } & $\mathrm{NaCl}$ & 3.136 & 0.0382 & 0.368 & 4.531 & 0.025 & 0.995 \\
\hline & $\mathrm{CaCl}_{2}$ & 1.751 & 0.060 & 0.403 & 4.019 & 0.015 & 0.990 \\
\hline & & \multicolumn{3}{|c|}{ Langmuir Model } & \multicolumn{3}{|c|}{ Freundlich Model } \\
\hline \multicolumn{2}{|c|}{ System } & $\frac{\mathrm{qm}_{\mathrm{m}}}{[\mathrm{mg} / \mathrm{g}]}$ & $\begin{array}{c}\mathrm{K}_{\mathrm{L}} \\
{[\mathrm{L} / \mathrm{mg}]}\end{array}$ & $\mathrm{R}^{2}$ & $\mathrm{n}$ & {$\left[\begin{array}{c}\mathrm{K}_{\mathrm{F}} \\
{\left[\mathrm{mg} / \mathrm{g}(\mathrm{mg} / \mathrm{L})^{-1 / \mathrm{nF}}\right]}\end{array}\right.$} & $\mathrm{R}^{2}$ \\
\hline Isotherms & $\mathrm{NaCl}$ & 4.768 & 0.186 & 0.999 & 4.454 & 0.218 & 0.887 \\
\hline & $\mathrm{CaCl}_{2}$ & 4.204 & 0.132 & 0.997 & 4.950 & 0.260 & 0.947 \\
\hline
\end{tabular}

The calculated $\mathrm{R}^{2}$ values for PSO equal 0.995 in $\mathrm{NaCl}$ and 0.990 in $\mathrm{CaCl}_{2}$, whereas the $\mathrm{R}^{2}$ values for PFO were 0.368 in $\mathrm{NaCl}$ and 0.403 in $\mathrm{CaCl}_{2}$. This indicates that $\mathrm{Cu}$ (II) adsorption on kaolinite involves electron sharing or exchange between adsorbent and adsorbate (chemisorption) [25].

The obtained adsorption isotherms of $\mathrm{Cu}(\mathrm{II})$ ions on the kaolinite surface, measured for two various supporting electrolytes $\left(\mathrm{NaCl}\right.$ or $\left.\mathrm{CaCl}_{2}\right)$ are presented in Figure 1c. The calculated isotherm parameters indicated that obtained experimental data are better fitted to Langmuir model (Table 1). In $0.001 \mathrm{M} \mathrm{NaCl}$ solution, the $\mathrm{R}^{2}$ value was 0.994 , whereas in $0.001 \mathrm{M} \mathrm{CaCl}_{2}-0.997$. Such a good fitting to the Langmuir model indicated that heavy metal ions formed monolayer on the kaolinite surface characterized by uniform adsorption energy $[17,26,27]$. At $\mathrm{pH} 5$, copper(II) ions occur mainly in the form of $\mathrm{Cu}^{2+}$. The concentration of $\mathrm{Cu}(\mathrm{OH})^{+}$species in the system is relatively low [28]. In the examined systems, $\mathrm{Cu}^{2+}$ ions interact with one or two adjacent surface groups according to reactions:

$$
\begin{aligned}
& -\mathrm{SO}^{-}+\mathrm{Cu}^{2+} \rightarrow-\mathrm{SO}-\mathrm{Cu}^{+} \\
& 2\left(-\mathrm{SO}^{-}\right)+\mathrm{Cu}^{2+} \rightarrow 2(-\mathrm{SO}) \mathrm{Cu}
\end{aligned}
$$

So, the adsorption layer formed on kaolinite may be positively charged and repel other heavy metal ions [28-30]. Due to this fact, the $\mathrm{Cu}$ (II) adsorbed amount on the selected clay mineral does not exceed $22 \%$. In addition to electrostatic interactions, $\mathrm{Cu}$ (II) adsorption on kaolinite may be connected by other mechanisms, i.e., ion exchange, surface complexation and van der Waals attractions [31]. The previous study on the adsorption of lead(II) and chromium(VI) ions on kaolinite also indicated the best fitting of adsorption isotherm data to Langmuir model [11,12,32].

Potentiometric titration of kaolinite showed that the point of zero charge $\left(\mathrm{pH}_{\mathrm{pzc}}\right)$ of the used clay mineral, determined in $0.001 \mathrm{M} \mathrm{NaCl}$, is about 3.7. In turn, in the solution of $0.001 \mathrm{M} \mathrm{CaCl}_{2}$ this parameter is about 4.1. This means that at $\mathrm{pH} 5$, at which adsorption measurements were carried out, the surface of kaolinite particles has a slight negative charge. In the $0.001 \mathrm{M} \mathrm{NaCl}$ solution the adsorbent surface charge equals $-3.2 \mu \mathrm{C} / \mathrm{cm}^{2}$, whereas in $0.001 \mathrm{M} \mathrm{CaCl}_{2}$ the $\sigma_{0}$ parameter is $-1.2 \mu \mathrm{C} / \mathrm{cm}^{2}$. Thanks to such adsorbent surface charge, copper(II) ions have a clear affinity to the solid surface (electrostatic attraction). Owing to stronger attractive forces occurring between heavy metal cations and kaolinite particles in the $\mathrm{NaCl}$ supporting electrolyte, the $\mathrm{Cu}(\mathrm{II})$ adsorbed amount was higher in this solution (compared to $\mathrm{CaCl}_{2}$ one). For initial $\mathrm{Cu}$ (II) concentration $100 \mathrm{mg} / \mathrm{L}$, in $0.001 \mathrm{M} \mathrm{NaCl} 4.36 \pm 0.25 \mathrm{mg} / \mathrm{g}(21.80 \pm 1.00 \%)$ of the ions were adsorbed, whereas in $0.001 \mathrm{M} \mathrm{CaCl}_{2}-3.76 \pm 0.20 \mathrm{mg} / \mathrm{g}(18.80 \pm 1.00 \%)$. The observed adsorbed amounts may be also associated with competition between bidentate cations (calcium and copper ones) present in the examined systems. The specific surface area occupied by the copper ions $\left(\mathrm{S}_{\mathrm{i}}\right)$ 
at equilibrium for $0.001 \mathrm{M} \mathrm{NaCl}$ was $0.91 \mathrm{~m}^{2} / \mathrm{g}$, whereas for $0.001 \mathrm{M} \mathrm{CaCl}_{2}-0.62 \mathrm{~m}^{2} / \mathrm{g}$. The cross-sectional area of $\mathrm{Cu}^{2+}$ ions is $1.58 \AA^{2}$ [20].

$\mathrm{The} \mathrm{Cu}(\mathrm{II})$ adsorption on kaolinite was confirmed using scanning electron microscope with EDS analyzer. The obtained map and element composition are presented in Figure 2.

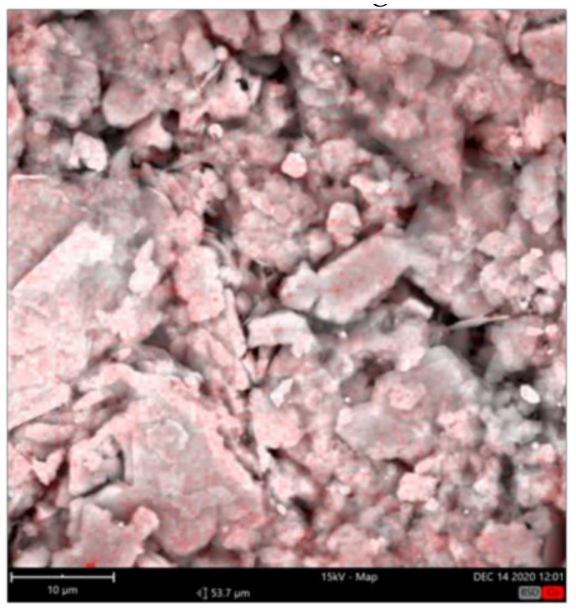

(a)

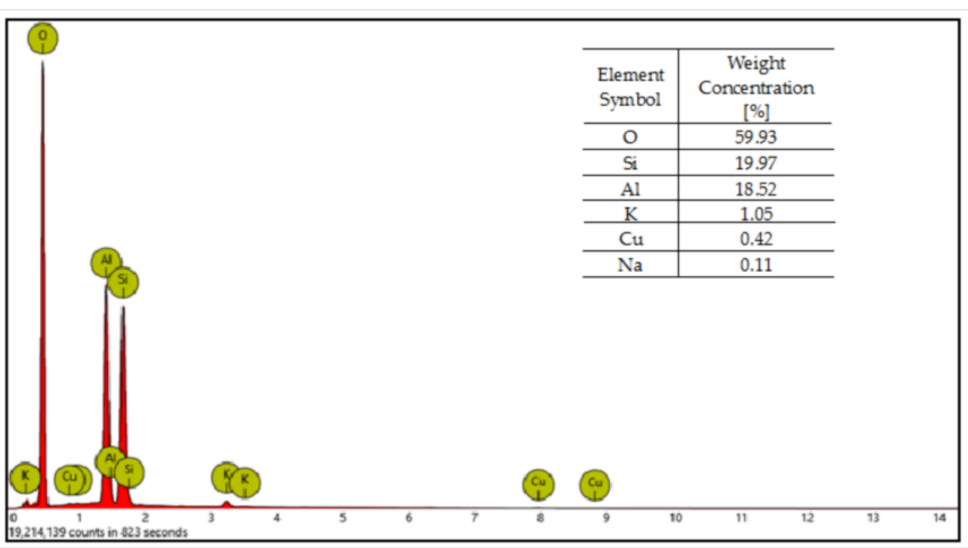

(b)

Figure 2. SEM-EDS maps (a) and elemental composition (b) of kaolinite after the Cu(II) adsorption (copper is marked in red).

\subsection{Mechanism of Exopolysaccharide Adsorption on the Kaolinite Surface}

The exopolysaccharide adsorbed amounts noted on the kaolinite surface are presented in Figure 3a.

(a)

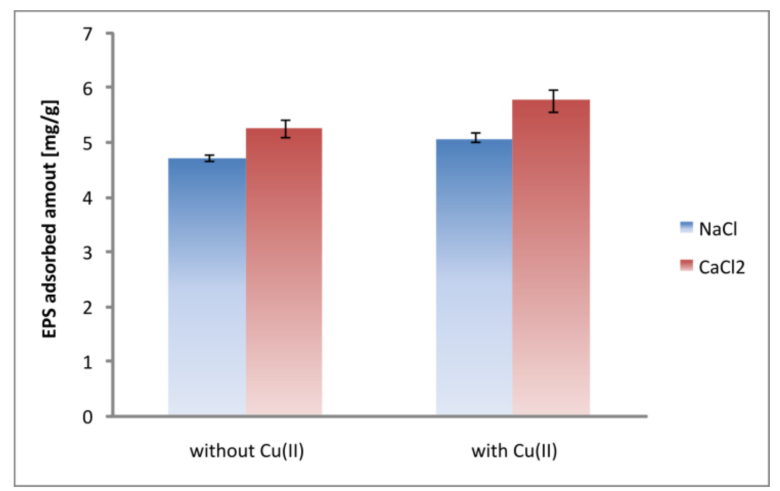

(b)

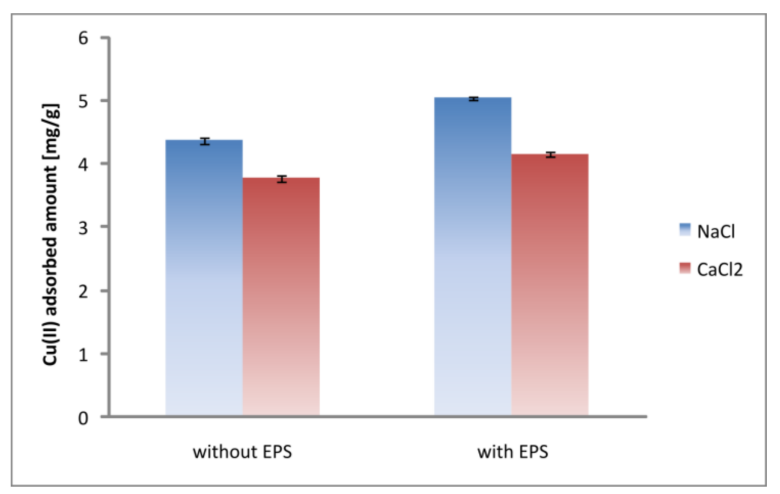

Figure 3. EPS adsorbed amount $[\mathrm{mg} / \mathrm{g}]$ without and with $\mathrm{Cu}(\mathrm{II})$ ions $(100 \mathrm{mg} / \mathrm{L})$ (a) as well as $\mathrm{Cu}$ (II) adsorbed amount $[\mathrm{mg} / \mathrm{g}]$ without and with EPS $(100 \mathrm{mg} / \mathrm{L})(\mathbf{b})$ in various supporting electrolytes (0.001 $\mathrm{M} \mathrm{NaCl}$ or $\mathrm{CaCl}_{2}$ ). 
The data obtained for EPS were not fitted to Langmuir nor Freundlich Equations because the adsorption of macromolecular compounds does not meet the assumptions of selected theoretical models. The results, presented as a histogram, showed that exopolysaccharide macromolecules were adsorbed on the kaolinite surface at $\mathrm{pH} 5$. However, the EPS adsorbed amounts were slightly higher in the $0.001 \mathrm{M} \mathrm{CaCl}_{2}$ solution (compared to $0.001 \mathrm{M} \mathrm{NaCl}$ one). For initial polymer concentration $100 \mathrm{mg} / \mathrm{L}$, in $0.001 \mathrm{M} \mathrm{NaCl}$ the EPS adsorbed amount was $4.69 \pm 0.08 \mathrm{mg} / \mathrm{g}(23.45 \pm 0.40 \%)$, whereas in $0.001 \mathrm{M}$ $\mathrm{CaCl}_{2}-5.26 \pm 0.15 \mathrm{mg} / \mathrm{g}(26.32 \pm 0.75 \%)$. Higher values observed in the system containing calcium chloride is dictated by more coiled structure of macromolecules in comparison to that assumed in the presence of sodium chloride. The previous studies indicated that, at $\mathrm{pH} 5$, the dissociation degree $(\alpha)$ of exopolysaccharide equals 0.94 . Thus, under these $\mathrm{pH}$ conditions, $94 \%$ of carboxylic groups are dissociated. The polymer segments containing negatively charged moieties repel each other, and as a consequence the EPS macromolecules have strongly expanded conformation. Calcium ions, owing to their bidentate character, may interact with two functional groups of the polymer chains. As a result, intra-molecular complexes, having more coiled conformation than uncomplexed macromolecules, are formed. During the adsorption, the EPS-Ca(II) complexes take a smaller part of adsorbent surface, so the adsorbed amount of the selected polymer may be larger. The formation of EPS- $\mathrm{Na}(\mathrm{I})$ complexes also occurs in the systems containing $\mathrm{NaCl}$ supporting electrolyte. However, this phenomenon does not change the conformation of polymer chains.

The exopolysaccharide adsorption on the kaolinite surface of slight negative charge is mainly based on the formation of hydrogen bonds between adsorbent and adsorbate functional groups. This mechanism is very possible in the presence of repulsive electrostatic forces acting between solid particles and polymer chains. The adsorption of S. meliloti exopolysaccharide was confirmed using Fourier transform infrared spectroscopy. The obtained spectra for kaolinite, EPS, as well as kaolinite covered with EPS are presented in Figure 4 .

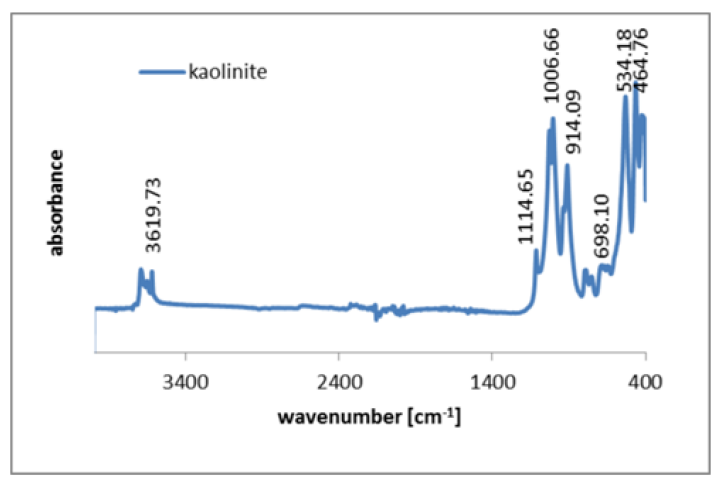

(a)

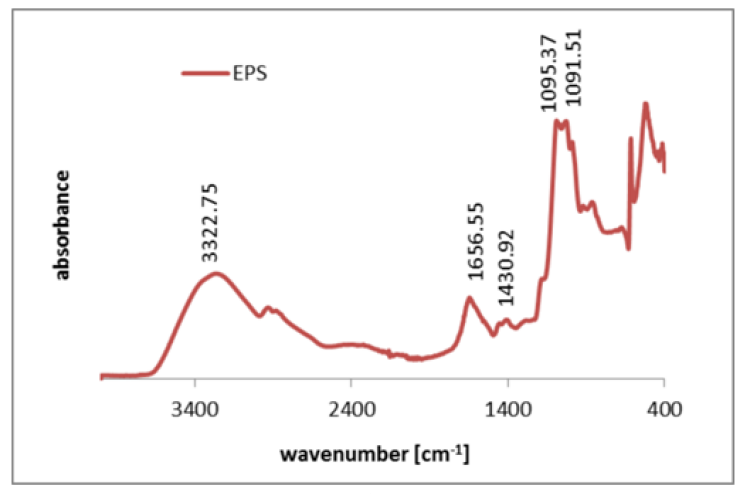

(b)

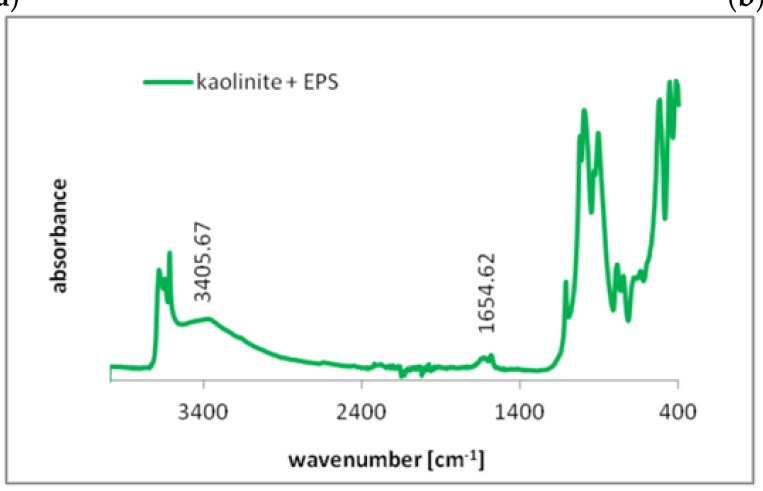

(c)

Figure 4. FTIR spectra of kaolinite (a), EPS (b) and kaolinite covered with EPS (c). 
The kaolinite spectrum contained band specific for this clay mineral. There were bands at:

1. 464.76 and $534.18 \mathrm{~cm}^{-1}$ (corresponding with Si-O stretching vibrations);

2. $\quad 698.10 \mathrm{~cm}^{-1}$ (attributed to $\mathrm{Mg} / \mathrm{Al}-\mathrm{OH}$ vibrations);

3. $800.31 \mathrm{~cm}^{-1}$ (the $\mathrm{Si}-\mathrm{O}-\mathrm{Al}$ group deformation);

4. $\quad 914.09 \mathrm{~cm}^{-1}$ (the $\mathrm{OH}$ bending vibrations of $\mathrm{Al}-\mathrm{OH}$ );

5. 1006.66 and $1114.65 \mathrm{~cm}^{-1}$ (the Si-O stretching) [33,34].

The spectrum of exopolysaccharide was composed of the following bands at: (1) 1091.51 and $1095.37 \mathrm{~cm}^{-1}$ (corresponding with $\mathrm{C}-\mathrm{H}$ bending vibrations); (2) $1430.92 \mathrm{~cm}^{-1}$ (attributed to $\mathrm{CH}_{2}$ symmetrical stretching); (3) $1656.55 \mathrm{~cm}^{-1}$ (the $-\mathrm{C}=\mathrm{C}$ stretching vibrations); (4) $3322.75 \mathrm{~cm}^{-1}$ (the $\mathrm{C}=\mathrm{C}-\mathrm{H}$ group stretching) [35]. The spectrum of the kaolinite particles obtained after EPS adsorption contained two specific bands, typical for selected macromolecular compound. They were at: (1) $1654.62 \mathrm{~cm}^{-1}$ (corresponding with $-\mathrm{C}=\mathrm{C}$ group stretching) and (2) $3405 \mathrm{~cm}^{-1}$ (attributed to $\mathrm{C}=\mathrm{C}-\mathrm{H}$ group stretching). These bands clearly confirmed the exopolysaccharide presence on the solid surface.

\subsection{Cu(II) and EPS Immobilization on Kaolinite in the Mixed Systems}

The adsorbed amounts of exopolysaccharide and copper(II) ions noted in the mixed systems, i.e., containing polymer and heavy metal ions simultaneously, are presented in Figure $3 a, b$. The experiments showed that EPS contributed to slight increase in the $\mathrm{Cu}(\mathrm{II})$ adsorbed amount on the kaolinite surface (Figure 3b). This means that in the S. meliloti exopolysaccharide presence, the immobilization of copper(II) ions on the clay mineral is higher. For initial $\mathrm{Cu}(\mathrm{II})$ concentration equal to $100 \mathrm{mg} / \mathrm{L}$, in the $0.001 \mathrm{M} \mathrm{NaCl}$ solution, the $\mathrm{Cu}(\mathrm{II})$ adsorbed amount was $5.03 \pm 0.17 \mathrm{mg} / \mathrm{g}(25.15 \pm 0.85 \%)$, in turn in the $0.001 \mathrm{M}$ $\mathrm{CaCl}_{2}$ solution $-4.15 \pm 0.15 \mathrm{mg} / \mathrm{g}(20.75 \pm 0.75 \%)$. The study on EPS-Cu(II) complexation indicated that, for initial $\mathrm{Cu}$ (II) concentration equal to $100 \mathrm{mg} / \mathrm{L}, 10.76 \pm 0.20 \mathrm{mg} / \mathrm{L}$ (in the $\mathrm{NaCl}$ system) and $2.06 \pm 0.05 \mathrm{mg} / \mathrm{L}$ (in $\mathrm{CaCl}_{2}$ ) of $\mathrm{Cu}$ (II) ions are bounded with the EPS macromolecules. In other words, $10.76 \pm 0.20 \%$ and $2.06 \pm 0.05 \%$ of heavy metal ions in $\mathrm{NaCl}$ and $\mathrm{CaCl}_{2}$, respectively, are arranged in the formation of complexes with macromolecular compound. Negative EPS macromolecules attract a certain amount of cations electrostatically. There may exist monocarboxylic and dicarboxylic complexes in the system [36]:

$$
\begin{gathered}
{\left[\mathrm{Cu}_{\mathrm{t}}\right]=\left[\mathrm{Cu}^{2+}\right]+\left[\mathrm{CuA}^{+}\right]+\left[\mathrm{CuA}_{2}\right]} \\
{\left[\mathrm{A}_{\mathrm{t}}\right]=\left[\mathrm{A}^{-}\right]+[\mathrm{HA}]+\left[\mathrm{CuA}^{+}\right]+2\left[\mathrm{CuA}_{2}\right]}
\end{gathered}
$$

where: $\left[\mathrm{Cu}_{t}\right],\left[\mathrm{A}_{\mathrm{t}}\right]$ - the total concentrations of copper(II) ions and carboxylic groups, $\left[\mathrm{CuA}^{+}\right],\left[\mathrm{CuA}_{2}\right],\left[\mathrm{A}^{-}\right]$- the concentrations of monocarboxylic copper(II) complexes, dicarboxylic copper(II) complexes and non-complexed carboxylic groups, respectively.

The bond between metal ion and polymer functional group may be also realized through coordinated bond (chelate complexes) or ionic bond (molecular complex) [37]. These EPS-Cu(II) complexes (in most of intra-molecular character) are adsorbed on the kaolinite surface together with free (uncomplexed) $\mathrm{Cu}$ (II) ions and, as a result, the heavy metal adsorbed amount increases. Owing to this phenomenon, the mobility and bioavailability of copper(II) ions to plants and animals in the soil environment enriched with Sinorhizobium meliloti exopolysaccharide are lower than in the soil without the selected EPS.

On the other hand, the $\mathrm{Cu}(\mathrm{II})$ ions presence in the examined system increases the exopolysaccharide adsorbed amount on kaolinite surface (Figure 3a). For initial EPS concentration equal to $100 \mathrm{mg} / \mathrm{L}$, in $0.001 \mathrm{M} \mathrm{NaCl}$, the EPS adsorbed amount was $5.04 \pm 0.16 \mathrm{mg} / \mathrm{g}$ $(25.20 \pm 0.80 \%)$, in turn in $0.001 \mathrm{M} \mathrm{CaCl}_{2}-5.76 \pm 0.20 \mathrm{mg} / \mathrm{g}(28.80 \pm 1.00 \%)$. As it was mentioned above, bidentate ions contribute to more coiled conformation of polymer chains by formation of intra-molecular complexes. Moreover, the concentration of copper(II) ions in the system is sufficiently high that they can participate in inter-molecular complexation. 
These complexes are created between adsorbed and non-adsorbed polymer chains and, as a result, the second adsorption layer of exopolysaccharide can be even formed.

\subsection{Copper(II) ions and Exopolysaccharide Effect on Kaolinite Surface Charge Density}

Potentiometric titration indicated that the point of zero charge $\left(\mathrm{pH}_{\mathrm{pzc}}\right)$ of kaolinite in $0.001 \mathrm{M} \mathrm{NaCl}$ equalled 3.7, whereas in $0.001 \mathrm{M} \mathrm{CaCl}_{2}$-4.1. At $\mathrm{pHs}<\mathrm{pH}_{\mathrm{pzc}}$ the solid surface charge is positive, in turn at $\mathrm{pHs}>\mathrm{pH}_{\mathrm{pzc}}$-negative. The results of conducted potentiometric titrations, i.e., the dependency of kaolinite surface charge density on the system $\mathrm{pH}$ value, are presented in Figure $5 \mathrm{a}, \mathrm{b}$.

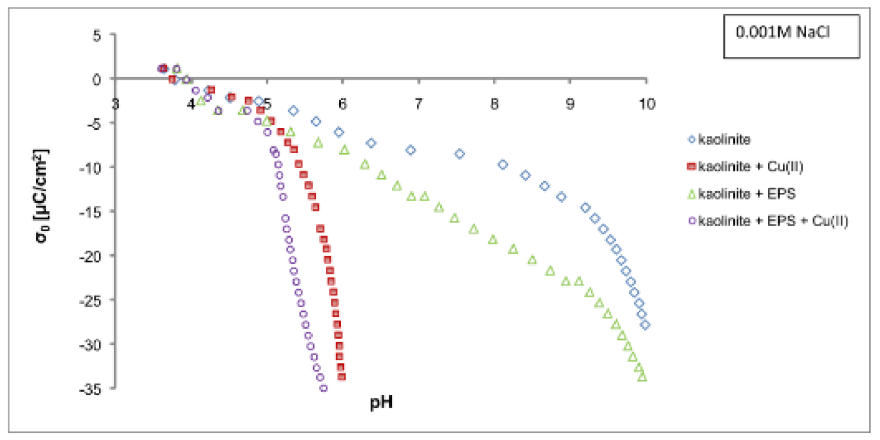

(a)

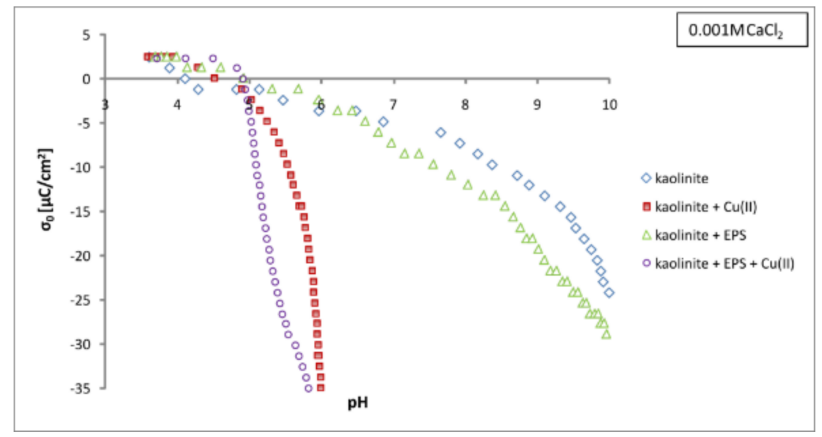

(b)

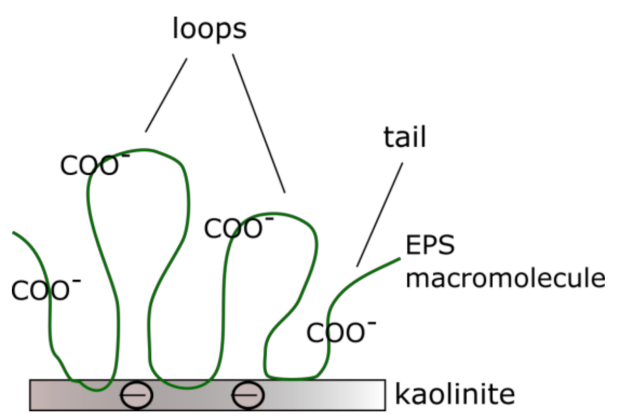

(c)

Figure 5. Surface charge density $\left(\sigma_{0}\right)$ of kaolinite in the absence and presence of $\mathrm{Cu}(\mathrm{II})$ ions and/or EPS (100 mg/L) in $0.001 \mathrm{M} \mathrm{NaCl}(\mathbf{a})$ and $0.001 \mathrm{M} \mathrm{CaCl}_{2}$ (b) as well as structures of EPS macromolecules on the kaolinite surface at pH 5 (c).

The value of $\mathrm{pH}_{\mathrm{pzc}}$ in $\mathrm{NaCl}$ and $\mathrm{CaCl}_{2}$ solution differs due to various adsorption mechanism of $\mathrm{Ca}^{2+}$ and $\mathrm{Na}^{+}$ions on kaolinite. The cations of the 1st group of metals and several monovalent anions (chloride, nitrate) show non-specific adsorption (based on electrostatic attraction) and, as a consequence, they do not affect the $\mathrm{pH}_{\mathrm{pzc}}$ parameter. The ions adsorbed non-specifically are located either in the diffuse Gouy-Chapman layer or at the outer Helmholz plane and separated from the surface by at least one water molecule [38-40]. The ions of calcium, i.e., of the metal from 2nd group, are also adsorbed in a specific way (based on chemical attraction (covalent or coordinate)). They are located in the inner Helmholz layer and may shift the $\mathrm{pH}_{\mathrm{pzc}}$ value significantly [40].

In the presence of copper(II) ions, regardless of supporting electrolyte type, the absolute values of negative kaolinite surface charge were higher than those noted without heavy metal ions. These changes in the $\sigma_{0}$ parameter were dictated by the following reactions between hydroxyl surface groups and $\mathrm{Cu}(\mathrm{II})$ ions [41]:

$$
\begin{gathered}
\equiv \mathrm{SOH}+\mathrm{Cu}^{2+} \rightleftharpoons \equiv \mathrm{SO}^{-} \mathrm{Cu}^{2+}+\mathrm{H}^{+} \\
2(\equiv \mathrm{SOH})+\mathrm{Cu}^{2+} \rightleftharpoons(\equiv \mathrm{SO})_{2} \mathrm{Cu}^{2+}+2 \mathrm{H}^{+} \\
\equiv \mathrm{SOH}+\mathrm{Cu}^{2+}+\mathrm{H}_{2} \mathrm{O} \rightleftharpoons \equiv \mathrm{SO}^{-} \mathrm{CuOH}^{+}+2 \mathrm{H}^{+}
\end{gathered}
$$


The exopolysaccharide addition to the examined suspensions also contributed to higher absolute values of negative kaolinite surface charge (compared to the solid surface charge noted without any adsorbates). This phenomenon, identical in two studied supporting electrolytes, was induced by dissociated carboxylic groups located in the 'loops' and 'tails' structures formed by exopolysaccharide on the kaolinite surface (Figure 5c). Due to negative charge of particles, the contact between them and EPS macromolecules is minimal. The polymer chains interact only with several surface groups; the vast majority of polymer segments is directed toward the solution. Thus, the number of carboxylic groups located in 'loops' and 'tails' structures is significantly higher than the number of the same moieties placed close to the kaolinite surface. 'Loops' and 'tails' are structures typical for macromolecular compounds adsorbed on the solid surface. Owing to them, one polymer chain can interact with several active sites on the adsorbent. 'Loops' and 'tails' were also observed in the following systems: poly(acrylic acid)/chromium(III) oxide [42], exopolysaccharide/silica [43], polyacrylamide/kaolinite [11].

In the mixed systems containing copper(II) ions and exopolysaccharide, in the case of both supporting electrolytes, the increase in absolute values of negative kaolinite surface charge was also noted. Probably, this is a result of combined impacts of heavy metal ions and exopolysaccharide adsorbed on the kaolinite particles.

\subsection{Exopolysaccharide and Copper(II) Ions Effect on Potential of Kaolinite Slipping Plane Area}

The obtained zeta potential values of kaolinite, in the absence and presence of copper(II) ions and exopolysaccharide, are presented in Figure 6.

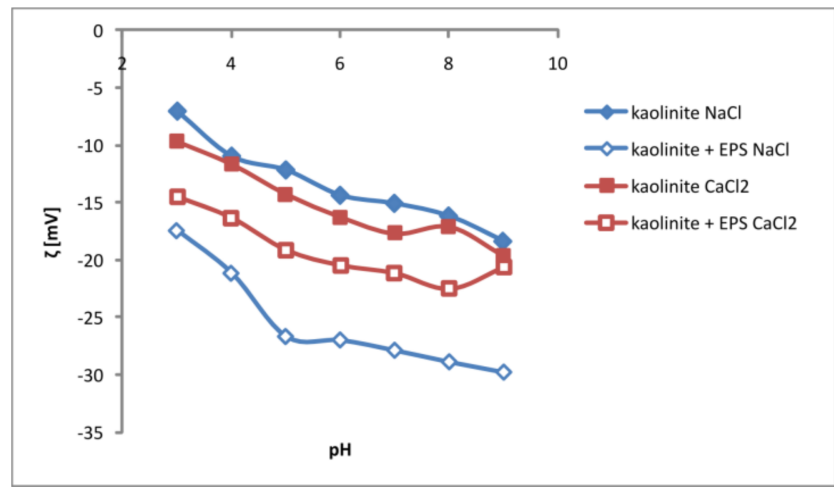

(a)

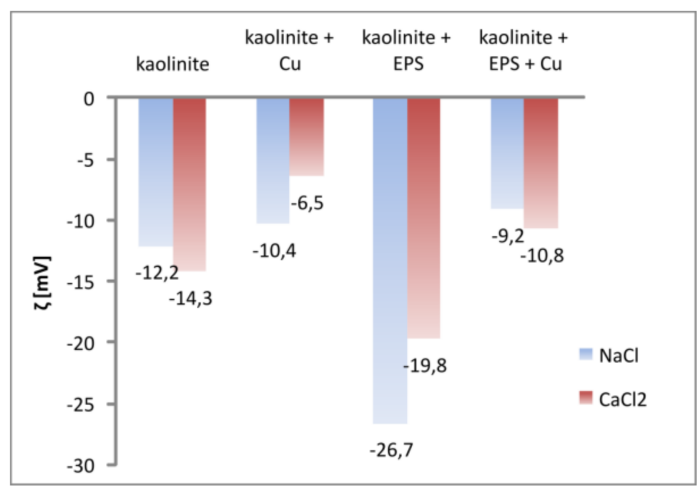

(b)

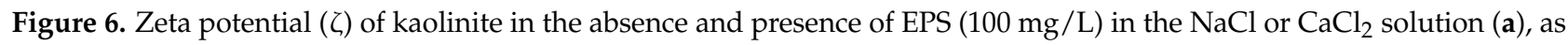
well as in the systems containing only $\mathrm{Cu}(\mathrm{II})$ ions $(100 \mathrm{mg} / \mathrm{L})$ or $\mathrm{Cu}(\mathrm{II})$ ions and EPS simultaneously (b).

Isoelectric point $\left(\mathrm{pH}_{\mathrm{iep}}\right)$ of kaolinite was not determined in the examined $\mathrm{pH}$ range of $3-9$. This means that the value of this parameter, both in $\mathrm{NaCl}$ and $\mathrm{CaCl}_{2}$ solution, is lower than 3. At the examined $\mathrm{pH}$ values (3-9), electrokinetic potential of kaolinite was negative, which indicated that negatively charged groups were dominant in the clay slipping plane area. The absolute values of negative zeta potential of kaolinite calculated for $\mathrm{NaCl}$ were minimally lower than those calculated for $\mathrm{CaCl}_{2}$.

Regardless of supporting electrolyte type, S. meliloti exopolysaccharide caused the increase in absolute values of negative kaolinite zeta potential (Figure 6a). This observation is associated with the slipping plane offset by the adsorbed EPS macromolecules, especially by 'loops' and 'tails' of considerable length. Higher absolute values of negative zeta potential are also dictated by dissociated carboxylic groups of polymer chains located in the slipping plane area.

The copper(II) ions presence in the kaolinite solution contributed to decrease in absolute values of negative zeta potential (compared to the suspension without adsorbates, Figure $6 \mathrm{~b}$ ). These changes are mainly associated with hydrated $\mathrm{Cu}(\mathrm{II})$ ions in the outer 
Helmholtz layer. They are adsorbed non-specifically based on electrostatic interactions [44]. The presence of both copper(II) ions and exopolysaccharide in the kaolinite suspension resulted also in a reduction in absolute values of negative zeta potential.

\subsection{Different Impacts of Exopolysaccharide and Copper(II) Ions on Kaolinite Aggregation}

The results of turbidimetry and particle size (CPS) analyses are presented in Figures 7 and 8 and Table 2.

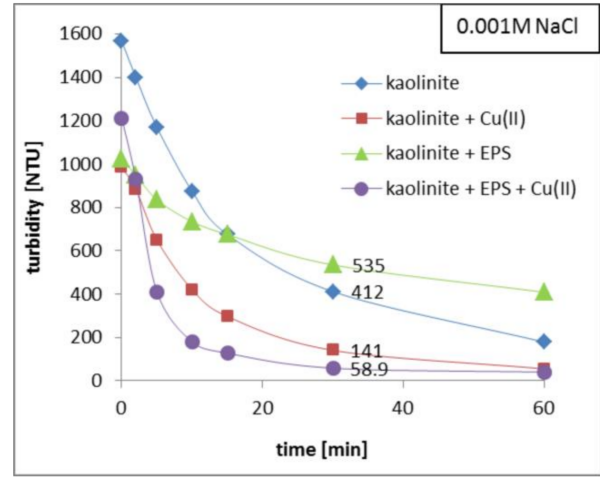

(a)

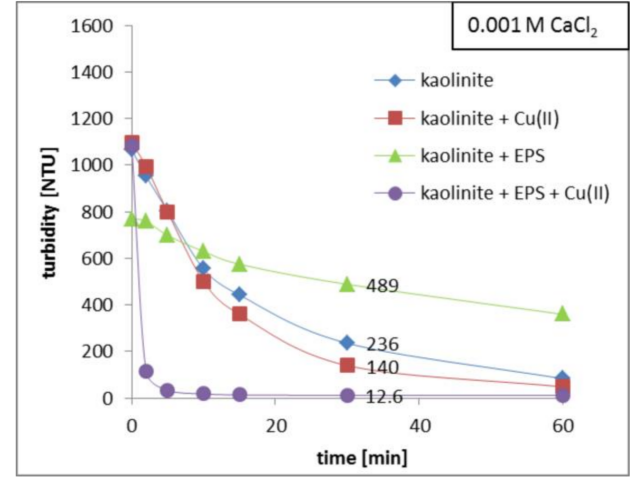

(b)

Figure 7. Turbidity changes in kaolinite suspension without and with $\mathrm{Cu}(\mathrm{II})$ ions and/or EPS $(100 \mathrm{mg} / \mathrm{L})$ in $0.001 \mathrm{M} \mathrm{NaCl}$ (a) and $0.001 \mathrm{M} \mathrm{CaCl}_{2}(\mathbf{b})$.

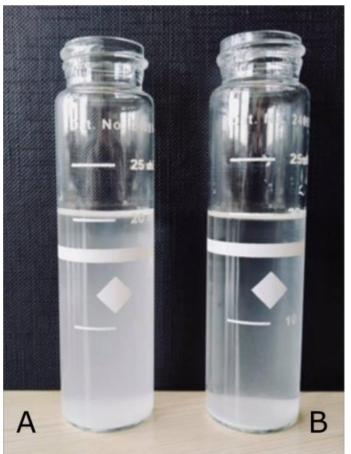

(a)

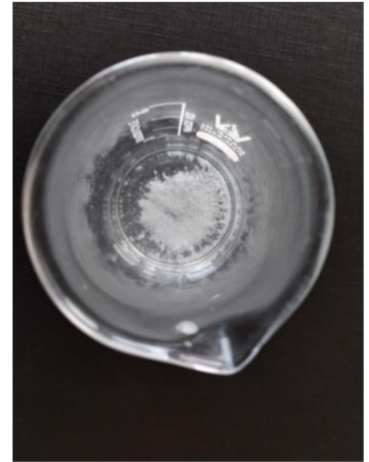

(b)

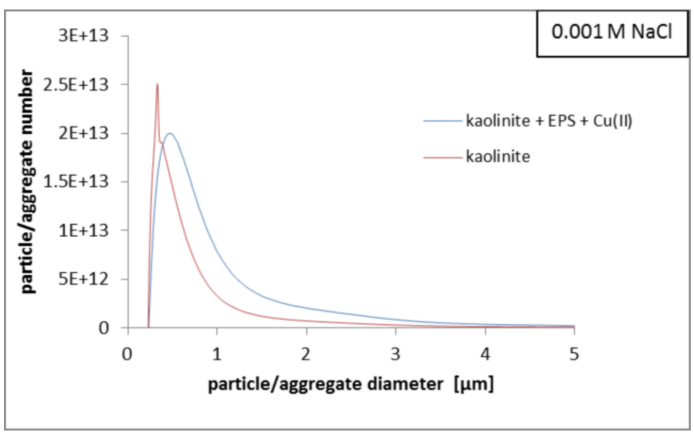

(c)

Figure 8. Photo of kaolinite suspension without(A) and with(B) EPS/Cu(II) ions after 15 min (a); photo of flocs formed in the kaolinite $/ \mathrm{Cu}(\mathrm{II}) / \mathrm{EPS} / \mathrm{CaCl}_{2}$ system $(\mathbf{b})$; particle/aggregate number vs . particle/aggregate diameter measured for kaolinite suspension without or with $\mathrm{Cu}$ (II) ions and EPS $(100 \mathrm{mg} / \mathrm{L})$ in $0.001 \mathrm{M} \mathrm{NaCl}(\mathbf{c})$. 
Table 2. Average diameter $[\mu \mathrm{m}]$ of particles/aggregates in kaolinite suspension prepared using two different supporting electrolytes; the CPS analyses were performed in the diameter range from 0.11 to $5 \mu \mathrm{m}$.

\begin{tabular}{|c|c|c|}
\hline \multicolumn{2}{|c|}{ System } & \multirow{2}{*}{$\begin{array}{l}(\mu \mathrm{m}) \\
0.329\end{array}$} \\
\hline Kaolinite & $\mathrm{NaCl}$ & \\
\hline Kaolinite + Cu(II) & - & 0.401 \\
\hline Kaolinite + EPS + Cu(II) & - & 0.488 \\
\hline Kaolinite & $\mathrm{CaCl}_{2}$ & 0.327 \\
\hline Kaolinite $+\mathrm{Cu}(\mathrm{II})$ & - & 0.371 \\
\hline Kaolinite + EPS + Cu(II) & - & 0.241 \\
\hline
\end{tabular}

They showed that copper(II) ions and S. meliloti exopolysaccharide, added to the system separately or simultaneously, influenced the kaolinite aggregation in a different way. However, the changes noted after addition of selected adsorbates were similar for both supporting electrolytes.

The strongest aggregation of kaolinite was observed in the mixed systems containing copper(II) ions and exopolysaccharide together. After $30 \mathrm{~min}$, the turbidity of the kaolinite $/ \mathrm{Cu}(\mathrm{II}) / \mathrm{EPS} / \mathrm{NaCl}$ system was $58.9 \mathrm{NTU}$, whereas that of kaolinite/Cu(II) $/ \mathrm{EPS} / \mathrm{CaCl}_{2}$ equalled only 12.6 NTU (Figure 7). For comparison, the turbidity of the kaolinite suspension without any adsorbate in $\mathrm{NaCl}$ after selected time was $412 \mathrm{NTU}$, in turn in $\mathrm{CaCl}_{2}-236 \mathrm{NTU}$. This indicated that in the simultaneous presence of heavy metal ions and polymer, the largest, quickly sedimenting aggregates are formed. Under these conditions, the clarification of the examined suspension is the fastest (Figure 8a). The CPS analyses showed that in the kaolinite suspension in $\mathrm{NaCl}$ the particles/aggregates of diameter $0.329 \mu \mathrm{m}$ prevailed, whereas in $\mathrm{CaCl}_{2}$ - those of $0.327 \mu \mathrm{m}$ were the most numerous. After addition of $\mathrm{Cu}(\mathrm{II})$ ions and $\mathrm{EPS}$, in the system containing $\mathrm{NaCl}$ the aggregates of diameter equal to $0.448 \mu \mathrm{m}$ were dominant. What is more, in the kaolinite $/ \mathrm{Cu}$ (II) $/ \mathrm{EPS} / \mathrm{CaCl}_{2}$ system the formed aggregates were so large that they exceeded the measuring range of the CPS device, i.e., $0.11-5 \mu \mathrm{m}$ (Figure $8 \mathrm{~b}$, Table 2). Stronger aggregation in the systems containing $\mathrm{CaCl}_{2}$ as a supporting electrolyte is dictated by bridging properties of calcium(II) cations [45].

Copper(II) ions, added to the kaolinite suspension separately, also contributed to stronger aggregation of solid particles, but to a lesser extent than $\mathrm{Cu}(\mathrm{II})$ ions and exopolysaccharide together. After $30 \mathrm{~min}$ the turbidity of the kaolinite $/ \mathrm{Cu}(\mathrm{II}) / \mathrm{NaCl}$ system was $141 \mathrm{NTU}$, whereas that of kaolinite/Cu(II)/ $\mathrm{CaCl}_{2}$ one-140 NTU.

On the other hand, the addition of only exopolysaccharide, regardless of supporting electrolyte type, contributed to higher turbidity of the kaolinite suspension. After $30 \mathrm{~min}$ the turbidity of the kaolinite/ $\mathrm{NaCl}$ system was $535 \mathrm{NTU}$, whereas that of kaolinite/ $\mathrm{CaCl}_{2}$ one-489 NTU. This means that the EPS presence limits the mutual contact between solid particles and hiders the aggregate formation.

The above phenomena are associated with several mechanisms. The reduction in suspension stability observed after the addition of copper(II) ions is mainly dictated by neutralization of negative surface charge of solid particles by adsorbed heavy metal cations. Under these conditions the absolute values of kaolinite zeta potential are the lowest among all tested systems, which also favors the solid aggregation (Figure 6b). In turn, the exopolysaccharide presence in the kaolinite suspension contributes to higher system stability based on electrosteric interactions [46]. The EPS macromolecules non-adsorbed or adsorbed on the solid surface create a steric barrier between the particles. What is more, carboxylic groups present in the polymer chains repel each other electrostatically. In this case, the absolute values of kaolinite zeta potential are the highest among all examined suspensions, which is equivalent to strong limitation in solid aggregation (Figure 6a). Clear system destabilization resulted in formation of big flocs (Figure 8b), noted in the mixed systems containing two adsorbate types, is mainly dictated by described-above creation of inter-molecular complexes between adsorbed polymer chains and copper(II) ions. Owing to this mechanism, the solid particles are bound together by specific bridges. 


\section{Conclusions}

The performed experiments allowed to define the nature of physicochemical interactions between copper(II) ions, S. meliloti exopolysaccharide and kaolinite. They enable the formulation of following conclusions:

1. Due to the competition between bidentate cations for access to the adsorbent surface, the $\mathrm{Cu}(\mathrm{II})$ adsorbed amount on kaolinite in $\mathrm{CaCl}_{2}$ solution was lower than that in $\mathrm{NaCl}$ supporting electrolyte. For initial $\mathrm{Cu}$ (II) concentration $100 \mathrm{mg} / \mathrm{L}$, in $0.001 \mathrm{M}$ $\mathrm{NaCl} 4.36 \pm 0.25 \mathrm{mg} / \mathrm{g}(21.80 \pm 1.00 \%)$ of the ions was adsorbed, whereas in $0.001 \mathrm{M}$ $\mathrm{CaCl}_{2}-3.76 \pm 0.20 \mathrm{mg} / \mathrm{g}(18.80 \pm 1.00 \%)$.

2. Regardless of electrolyte type, the experimental data of $\mathrm{Cu}(\mathrm{II})$ adsorption isotherms were best fitted to Langmuir model. This indicated, inter alia, that heavy metal ions formed monolayer on the clay mineral surface characterized by uniform adsorption energy. The kinetics of the $\mathrm{Cu}(\mathrm{II})$ adsorption on kaolinite were best fitted to the pseudo second-order equation, which meant that the examined phenomenon involved chemisorption.

3. The adsorbed amount of exopolysaccharide on kaolinite was larger in the $\mathrm{CaCl}_{2}$ electrolyte than in $\mathrm{NaCl}$ one. For initial polymer concentration $100 \mathrm{mg} / \mathrm{L}$, in $0.001 \mathrm{M}$ $\mathrm{NaCl}$ the EPS adsorbed amount was $4.69 \pm 0.08 \mathrm{mg} / \mathrm{g}(23.45 \pm 0.40 \%)$, whereas in $0.001 \mathrm{M} \mathrm{CaCl}_{2}-5.26 \pm 0.15 \mathrm{mg} / \mathrm{g}(26.32 \pm 0.75 \%)$. This is a result of the formation of intra-molecular EPS-Ca(II) complexes having more coiled conformation than uncomplexed macromolecules.

4. In the mixed system, exopolysaccharide contributed to higher adsorption level of copper(II) ions. What is more, heavy metal ions also make the exopolysaccharide adsorbed amount on the clay mineral larger. The above observations are mainly associated with $\mathrm{Cu}(\mathrm{II})$ ions-EPS complexation.

5. Adsorption of copper(II) ions and/or S. meliloti exopolysaccharide affected the structure of electrical double layer of kaolinite, significantly. There are clear changes in zeta potential values and surface charge of clay mineral.

6. In the samples containing $\mathrm{Cu}(\mathrm{II})$ ions and exopolysaccharide simultaneously, the kaolinite aggregation was the strongest. This is mainly dictated by the formation of specific bridges (consisted of polymer chains and heavy metal ions) between solid particles.

7. In the environment contaminated with copper(II) ions, Sinorhizobium meliloti exopolysaccharide contributes to a higher immobilization of selected heavy metal as well as stronger aggregation of clay minerals, which is highly desirable in soil remediation technologies.

Author Contributions: Conceptualization, K.S.-K.; methodology, K.S.-K., A.T., I.K., A.A., and W.S.C.; software, K.S.-K., A.T., A.A., and W.S.-C.; validation, K.S.-K., I.K., and A.C.; formal analysis, K.S.-K., and A.C.; investigation, K.S.-K., A.T., I.K., A.C., A.A., and W.S.-C.; resources, K.S.-K., and I.K.; data curation, K.S.-K.; writing—original draft preparation, K.S.-K., and A.T.; writing-review and editing, K.S.-K. and A.T.; visualization, K.S.-K., A.A., and A.T.; supervision, K.S.-K. and A.C.; project administration, K.S.-K.; funding acquisition, K.S.-K., A.C, and W.S.-C. All authors have read and agreed to the published version of the manuscript.

Funding: No external funds were received. All works were done within the statutory activity of the Institute of Agrophysics PAS and Maria Sklodowska-Curie University in Lublin.

Institutional Review Board Statement: Not applicable.

Informed Consent Statement: Not applicable.

Data Availability Statement: The reported results can be found at the Institute of Agrophysics, PAS, Lublin, Poland.

Acknowledgments: We would like to thank Agnieszka Nawrocka and Jolanta Cieśla for their laboratory support. 
Conflicts of Interest: The authors declare no conflict of interest.

\section{References}

1. Kopcewicz, J.; Lewak, S. Plant Physiology; PWN: Warsaw, Poland, 2002. (In Polish)

2. Janczarek, M.; Mazur, A.; Wielbo, J.; Król, J.; Skorupska, A. Rhizobial exopolisaccharides: Structure, biosynthesis, function in symbiosis. Microbiol. Progres. 1999, 38, 217.

3. Sutherland, I.W. Bacterial exopolysaccharides. Adv. Microb. Physiol. 1972, 8, 143-213. [PubMed]

4. Skorupska, A.; Janczarek, M.; Marczak, M.; Mazur, A.; Król, J. Rhizobial exopolysaccharides: Genetic control and symbiotic functions. Microb. Cell Fact. 2006, 5, 7. [CrossRef]

5. Reinhold, B.B.; Chan, S.Y.; Reuber, T.L.; Marra, A.; Walker, G.C.; Reinhold, V.N. Detailed structural characterization of succinoglycan, the major exopolysaccharide of Rhizobium meliloti Rm1021. J. Bacteriol. 1994, 176, 1997-2002. [CrossRef] [PubMed]

6. Urzainqui, A.; Walker, G.C. Exogenous suppression of the symbiotic deficiencies of Rhizobium meliloti exo mutants. J. Bacteriol. 1992, 174, 3403-3406. [CrossRef] [PubMed]

7. Zhang, M.K.; Liu, Z.Y.; Wang, H. Use of single extraction methods to predict bioavailability of heavy metals in polluted soils to rice. Commun. Soil Sci. Plant Anal. 2010, 41, 820-831. [CrossRef]

8. Liang, W.; Shen, Q.; Gao, Y.; Gu, X.; Yang, Z. Use of bentonite to control the release of copper from contaminated soils. Aust. J. Soil Res. 2007, 45, 618-623. [CrossRef]

9. Kirpichtchikova, T.A.; Manceau, A.; Spadini, L.; Panfili, F.; Marcus, M.A.; Jacquet, T. Speciation and solubility of heavy metals in contaminated soil using X-ray microfluorescence, EXAFS spectroscopy, chemical extraction, and thermodynamic modeling. Geochim. Cosmochim. Acta 2006, 70, 2163-2190. [CrossRef]

10. Zhang, X.; Wang, X.-Q.; Wang, D.-F. Immobilization of heavy metals in sewage sludge during land application process in China: A Review. Sustainability 2017, 9, 2020. [CrossRef]

11. Fijałkowska, G.; Szewczuk-Karpisz, K.; Wiśniewska, M. Anionic polyacrylamide as a substance strengthening the Pb(II) immobilization on the kaolinite surface. Int. J. Environ. Sci. Technol. 2020, 17, 1101-1112. [CrossRef]

12. Szewczuk-Karpisz, K.; Fijałkowska, G.; Wiśniewska, M.; Wójcik, G. Chromium(VI) reduction and accumulation on the kaolinite surface in the presence of cationic soil flocculant. J. Soil Sediments 2020, 20, 3688-3697. [CrossRef]

13. Jiang, M.-Q.; Jin, X.-Y.; Lu, X.-Q.; Chen, Z.-L. Adsorption of Pb(II), Cd(II), Ni(II) and Cu(II) onto natural kaolinite clay. Desalination 2010, 252, 33-39. [CrossRef]

14. Wu, P.; Zhang, Q.; Dai, Y.; Zhu, N.; Dang, Z.; Li, P.; Wu, J.; Wang, X. Adsorption of Cu(II), Cd(II) and Cr(III) ions from aqueous solutions on humic acid modified Ca-montmorillonite. Geoderma 2011, 164, 215-219. [CrossRef]

15. Szewczuk-Karpisz, K.; Wiśniewska, M.; Pac, M.; Choma, A.; Komaniecka, I. Sinorhizobium meliloti 1021 exopolysaccharide as a flocculant improving chormium(III) oxide removal from aqueous solutions. Water Air Soil Pollut. 2014, 225, 2052. [CrossRef] [PubMed]

16. Vincent, J.M. A Manual for the Practical Study of Root Nodule Bacteria. International Biological Program Handbook No. 15; Blackwell Scientific Publications Ltd.: Oxford, UK, 1970.

17. Ościk, J. Adsorption; UMCS: Lublin, Poland, 1969. (In Polish)

18. Mehling, J. Colorimetric determination of copper with ammonia. Ind. Eng. Chem. Anal. Ed. 1941, 13, 533-535. [CrossRef]

19. Foo, K.Y.; Hameed, B.H. Insight into the modeling of adsorption isotherm systems. Chem. Eng. J. 2010, 156, 2-10. [CrossRef]

20. Ho, Y.S.; Huang, C.T.; Huang, H.W. Equilibrium sorption isotherm for metal ions on tree fern. Process Biochem. 2002, 37, 1421-1430. [CrossRef]

21. Ho, Y.S.; McKay, G. Sorption of dye from aqueous solution by peat. Chem. Eng. J. 1998, 70, 115-124. [CrossRef]

22. Ho, Y.S.; McKay, G. Application of kinetics models to the sorption of copper(II) onto peat. Adsorption Sci. Technol. 2002, 20, 797-815. [CrossRef]

23. Janusz, W. Electrical double layer at the metal oxide/electrolyte interface in interfacial forces and fields: Theory and applications. In Surfactant Science Series; Decker, M., Ed.; Marcel Dekker Inc.: New York, NY, USA, 1994; Volume 85, Chapter 4.

24. Oshima, H. A simple expansion for Henry's function for the retardation effect in electrophoresis of spherical colloidal particles. $J$. Colloid Interface Sci. 1994, 168, 269-271. [CrossRef]

25. Wang, H.; Zhou, A.; Peng, F.; Yu, H.; Yang, J. Mechanism study on adsorption of acidified multiwalled carbon nanotubes to Pb(II). J. Colloid Interface Sci. 2007, 316, 277-283. [CrossRef]

26. Paderewski, M.L. Adsorption Processes in Chemical Engineering; WNT: Warsaw, Poland, 1999. (In Polish)

27. Zhang, Z.; Xia, S.; Wang, X.; Yang, A.; Xu, B.; Chen, L.; Zhu, Z.; Zhao, J.; Jaffrezic-Renault, N.; Leonard, D. A novel biosorbent for dye removal: Extracellular polymeric substance of Proteus mirabilis TJ-1. J. Hazard. Mater. 2009, 163, 279-284. [CrossRef]

28. Hoslett, J.; Ghazal, H.; Ahmad, D.; Jouhara, H. Removal of copper ions from aqueous solution using low temperature biochar derived from the pyrolysis od municipal solid waste. Sci. Total Environ. 2019, 673, 777-789. [CrossRef] [PubMed]

29. Jin, H.; Hanif, M.U.; Capareda, S.; Chang, Z.; Huang, H.; Ai, Y. Copper(II) removal potential from aqueous solution by pyrolysis biochar derived from anaerobiocally digested algae-dairy-manure and effect of KOH activation. J. Environ. Chem. Eng. 2016, 4, 365-372. [CrossRef] 
30. Albrecht, T.W.J.; Addai-Mensah, J.; Fornansiero, D. Effect of $\mathrm{pH}$, concentration and temperature on copper and zinc hydroxide formation/precipitation in solution. In Proceedings of the CHEMECA 2011-'Engineering a Better World', Sydney, NSW, Australia, 18-21 September 2011.

31. Li, H.; Dong, X.; da Silva, E.B.; de Oliveira, L.M.; Chen, Y.; Ma, L.Q. Mechanisms of metal sorption by biochars: Biochar characteristics and modifications. Chemosphere 2017, 178, 466-478. [CrossRef]

32. Fijłakowska, G.; Wiśniewska, M.; Szewczuk-Karpisz, K.; Jędruchniewicz, K.; Oleszczuk, P. Comparison of lead(II) ions accumulation and bioavailability on the montmorillonite and kaolinite surfaces in the presence of polyacrylamide soil flocculant. Chemosphere 2021, 276, 130088. [CrossRef]

33. Gild, M.; Sobrados, I.; Rhaiem, H.B.; Sanz, J.; Amara, A.B.H. Alkaline activation of metakaolinite-silica mixtures: Role of dissolved silica concentration on the formation of geopolymers. Ceramics Int. 2017, 43, 12641-12650. [CrossRef]

34. Tironi, A.; Trezza, M.A.; Irassar, E.F.; Scian, A.N. Thermal treatment of kaolin: Effect on the pozzolanic activity. 11th International Congress on Metallurgy \& Materials SAM/CONAMET 2011. Procedia Mater Sci. 2012, 1, 343-350.

35. Borah, T.; Gogoi, B.; Khataniar, A.; Gogoi, M.; Das, A.; Borah, D. Probiotic characterization of indigenous Bacillus velezensis strain DU14 isolated from Apong, a traditionally fermented rice beer of Assam. Biocatal. Agric. Biotechnol. 2019, 18, 101008. [CrossRef]

36. Yamashita, F.; Komatsu, T.; Nakagawa, T. Study of metal-polycarboxylate complexes employing ion-selective electrodes. II. Stability constants of copper(II) complexes with poly(acrylic acid) and poly(methacrylic acid). Bullet. Chem. Soc. Jpn. 1978, 52, 30-33. [CrossRef]

37. Tarabukina, E.B.; Fatullaev, E.I.; Filippov, A.P.; Abzaeva, K.A. Behavior of metal complexes of polyacrylic acid in solutions. Int. J. Polym. Anal. Charact. 2018, 24, 10-17. [CrossRef]

38. Parks, G.A. The isoelectric points of solid oxides, solid hydroxides and aqueous hydroxo complex systems. Chem. Rev. 1965, 65, 177-198. [CrossRef]

39. Kosmulski, M. The pH dependent surface charging and points of zero charge. VIII. Update. Adv. Colloid Interface Sci. 2020, 275, 102064. [CrossRef]

40. Wakatsuki, T.; Furukawa, H.; Kawaguchi, K. Specific and non-specific adsorption of inorganic ions I. Evaluation of specific absorbability by means of minimum concentration for specific adsorption. Soil Sci. Plant Nutri. 1974, 20, 353-362. [CrossRef]

41. Skwarek, E.; Janusz, W.; Sternik, D. Adsorption of citrate ions on hydroxyapatite synthetized by various methods. J. Radioanal. Nucl. Chem. 2014, 299, 2027-2036. [CrossRef] [PubMed]

42. Wiśniewska, M.; Szewczuk-Karpisz, K. Removal possibilities of colloidal chromium(II) oxide from water using polyacrylic acid. Environ. Sci. Pollut. Res. 2012, 20, 3657-3669. [CrossRef]

43. Szewczuk-Karpisz, K.; Wiśniewska, M.; Pac-Sosińska, M.; Choma, A.; Komaniecka, I. Stability mechanism of the silica suspension in the Sinorhiobium meliloti 1021 exopolysaccharide presence. J. Ind. Eng. Chem. 2015, 35, 108-114. [CrossRef]

44. Birdi, K.S. Handbook of Surface and Colloid Chemistry, 2nd ed.; CRS Press: Boca Raton, NY, USA, 2003.

45. Rowley, M.C.; Grand, S.; Verrecchia, E.P. Calcium-mediated stabilisation of soil organic carbon. Biogeochemistry 2018, 137, 27-49. [CrossRef]

46. Wiśniewska, M.; Szewczuk-Karpisz, K. Comparison of stability properties of nanozirconia aqueous susupension in the presence of selected biopolymers. Springer Proc. Phys. 2016, 183, 261-273. 